\title{
A note from the President
}

\author{
José J. G. Moura
}

(C) SBIC 2011

\section{The Society of Biological Inorganic Chemistry}

SBIC has been established as a learned society of advanced research and education in the field of Biological Inorganic Chemistry

\section{SBIC COUNCIL}

\section{President}

José J.G. Moura, Lisbon, Portugal

\section{Past President}

Trevor Hambley, Sydney, Australia

\section{Secretary}

Charles Riordan, Newark, DE, USA

\section{Treasurer}

Graeme Hanson, St. Lucia, Australia

\author{
Members \\ Victoria A. DeRose, Eugene, OR, USA \\ Julia A. Kovacs, Seattle, WA, USA \\ Janet R. Morrow, Amherst, NY, USA \\ Stephen W. Ragsdale, Ann Arbor, MI, USA \\ Britt-Marie Sjöberg, Stockholm, Sweden \\ Paola Turano, Florence, Italy \\ Alcjandro J. Vila, Rosario, Argentina
}

\author{
Chief Editor of JBIC \\ Program Committee/ICBIC-IOC \\ Nominations Committee \\ Lucia Banci, Florence, Italy \\ SBIC Website: \\ http://SBIChem.org
}

Lawrence Que Jr., Minneapolis, MN, USA

Kenneth D. Karlin, Baltimore, MD, USA
Nature inspired...

The renaissance of Organometallic Chemistry and challenges for Inorganic Chemists.

$\mathrm{B}_{12}$ containing cofactors has been the example used by organometallic chemistry to make the link with biology for a long time. However, in recent years the number of organometallic compounds recognized to be present in biology has been increasing (Adams M.W. and Stiefel E.I., "Organometallic iron: the key to biological hydrogen metabolism", Curr Opin Chem Biol [2000] 214-20 and many others). Nowadays it is easy to convince an inorganic chemistry student of the relevance of the discipline in biology-related problems. The $\mid \mathrm{Fe}-\mathrm{Nil}$ and $\mid \mathrm{Fe}$-only| hydrogenases, as well as $\mid \mathrm{Fe}-\mathrm{Nil} \mathrm{CO}$ dehydrogenase, are excellent and appealing examples, among others. In biological systems, metalloenzymes (with optimized active sites and structures) carry out complex and challenging reactions. The geometries of these active sites are tightly controlled and the entire environment plays a crucial role in the fine-tuning of the reaction pathways. Organometallic chemistry can be the bridge between inorganic, organic, and biological chemistry, generating questions and giving answers for reaction mechanisms, control of enzymatic rates, and the synthesis of bio-inspired models through experimental and theoretical studies. A recent article (Higgins S.J., Nichols R.J., Martin S., Cea P., van der Zant H.S.J., Richter M.M. and Low P.J., Organometallics [2011] 30, 7-12) looks ahead for challenges and future opportunities in organometallic chemistry, prompted by these challenging active metal sites and mimicking what is found in nature. Inorganic chemistry also parallels these problems. Out there, biological unique inorganic structures await the development of structural and functional models. Transformations of elemental biocycles and photocatalysis where complexity of electron-transfer reactions often couple with proton transfer are examples of topics of importance for the design of biomimetic or bioinspired models. A straightforward example is the novel tetra-nuclear copper site (designated as $\mathrm{CuZ}$ ) in the terminal enzyme of the denitrification pathway (Nitrogen biocycle)—nitrous oxide reductase, where a bioinspired model is absolutely needed (Dell'Acqua S., Pauleta S.R., Moura I. and Moura J.J.G., "The tetranuclear copper active site of nitrous oxide reductase: the CuZ center", J Biol Inorg Chem [2011] 16, 183-94). Bioinorganic Chemistry will be the right umbrella to convene Organometallic and Inorganic Chemists.

José J. G. Moura

President SBIC 